\title{
Active polyketides isolated from Penicillium herquei
}

\author{
ANDREY M.R. MARINHO ${ }^{1}$, PATRÍCIA S.B. MARINHO ${ }^{1}$, LOURIVALDO S. SANTOS $^{1}$, \\ EDSON RODRIGUES FILHO ${ }^{2}$ and IZABEL C.P. FERREIRA ${ }^{3}$ \\ ${ }^{1}$ Faculdade de Química, Universidade Federal do Pará, Rua Augusto Corrêa, 01, 66075-110 Belém, PA, Brasil \\ ${ }^{2}$ Departamento de Química, Universidade Federal de São Carlos, \\ Rod. Washington Luiz Km 235, 13565-905 São Carlos, SP, Brasil \\ ${ }^{3}$ Departamento de Análises Clínicas, Universidade Estadual de Maringá, Av. Colombo, 5790, 87020-900 Maringá, PR, Brasil
}

Manuscript received on September 15, 2011; accepted for publication on January 10, 2013

\begin{abstract}
In this work we are reporting the isolation by classical methods of chromatography of six polyketides from Penicillium herquei. The compounds citreorosein (1), emodin (2), janthinone (3), citrinin (4), citrinin H1 (5) and dicitrinol (6) were identified by spectral methods of 1D and 2D NMR and MS. Compounds 1, 2 and 3 were tested against promastigotes forms of Leishmania brasiliensis and 1 and 2 were also assayed against Escherichia coli, Pseudomonas aeruginosa and Bacillus subtilis and showed good activity.
\end{abstract}

Key words: polyketides, biological assay, P. herquei.

\section{INTRODUCTION}

The search for substances with useful biological activities to man is one of the most studied fields in science as a whole. There is always the need to renew the arsenal of active compounds due to the parasites acquire resistance to drugs already on the market, as well as the emergence of new diseases.

Fungi are good producers of secondary metabolites, many with useful biological activity (Petrini et al. 1992, Jarvis and Miller 1996, Li et al. 1998, Stierle et al. 1995). Endophytic fungi often produce substances that can help the host plant to fight infestations by other fungi, bacteria and viruses, even assisting in its development (Shittu et al. 2009, Hamayun et al. 2009). Since

Correspondence to: Andrey M.R. Marinho

E-mail: andrey@ufpa.br such substances can also be useful for people, it is therefore of great importance to study the biological activities of substances produced by endophytic fungi.

In this paper we report the isolation of six polyketides citreorosein (1), emodin (2), janthinone (3), citrinin (4), citrinin H1 (5) and dicitrinol (6) (Figure 1). Compounds 1, 2 and 3 were tested against promastigote forms of Leishmania brasiliensis and 1 and 2 were also assayed for antimicrobial activities.

\section{MATERIALS AND METHODS}

\section{General Procedures}

The IR spectrum was measured in BOMEN MB-102 spectrophotometer in $\mathrm{KBr}$ pellet. APCIMS data were acquired in negative mode using a MICROMASS 
<smiles>O=C1c2cc(O)cc(O)c2C(=O)c2c(O)cc(CO)cc21</smiles><smiles>Cc1cc(O)c2c(c1)C(=O)c1cc(O)cc(O)c1C2=O</smiles><smiles>COc1cccc2c(=O)c3c(O)cc(C)cc3oc(=O)c12</smiles><smiles>CC1OC=C2C=C(O)C(=O)C(C(=O)O)=C2C1C</smiles>

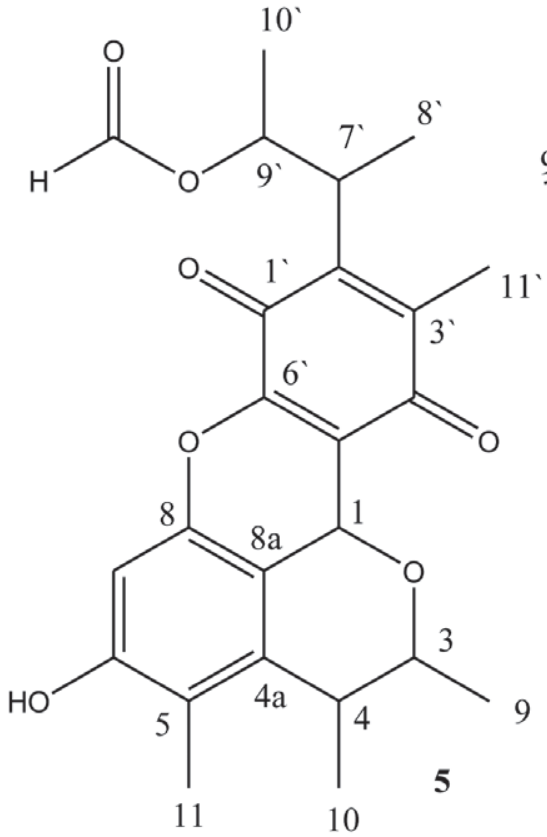

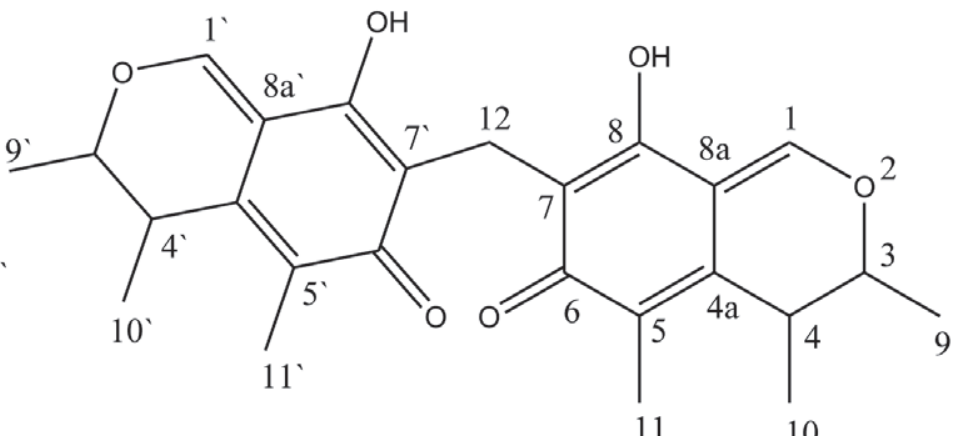

6

Figure 1 - polyketides isolated from $P$. herquei.

QUATTRO-LC instrument (Waters, Manchester United Kingdom) equipped with an ESI/APCI ion source "Z-spray" type. ${ }^{1} \mathrm{H}$ and ${ }^{13} \mathrm{C}$ NMR experiments were obtained in a BRUKER DRX-400 spectrometer (Bruker Daltonics, Germany) in $\mathrm{CDCl}_{3}$ with TMS as internal standard. 


\section{MICROORGANISM}

P. herquei belong to the collection of the Laboratório de Bioquímica Micromolecular de Microorganismos, Departamento de Química - Universidade Federal de São Carlos and it is identified by the number LaBioMi 019. This collection contains isolates from Melia azedarach (Santos et al. 2003).

Culture of P. herqueii in Rice and Polyketides Isolation

Forty-five Erlenmeyer flasks $(500 \mathrm{~mL})$ containing $90 \mathrm{~g}$ rice ("Uncle's Been's ${ }^{\circledR}$ ") and $75 \mathrm{~mL}$ distilled water per flask were autoclaved for $45 \mathrm{~min}$ at $121^{\circ} \mathrm{C}$. Small cubes of PDA medium containing mycelium of $P$. herquei were added in 42 Erlenmeyer flasks under sterile condition. Three flasks were used as control. After 20 days of growth at $25^{\circ} \mathrm{C}$ the biomass obtained was macerated with dichloromethane, ethyl acetate and methanol. The dichloromethane solution was evaporated under reduced pressure, producing a yellowish residue (24.2 g). Part of this residue $(10.0 \mathrm{~g})$ was subjected to a low-pressure silica gel CC eluted with $n$-hexane, ethyl acetate and methanol gradient. The medium polarity fractions eluted with ethyl acetate were repeatedly chromatographed on silica gel CC eluted with n-hexane, acetone and methanol gradient. Finally, they provide the polyketides citreorosein (1), emodin (2), janthinone (3), citrinin (4), citrinin H1 (5) and dicitrinol (6).

\section{LEISHMANICIDAL ASSAY}

Promastigote forms of Leishmania viannia braziliensis MHOM/BR1987/M11272 were grown at $25^{\circ} \mathrm{C}$ in Schneider's Drosophila medium supplemented with $10 \%$ fetal calf serum(FCS). Cells were collected at logarithmic phase, resuspended in fresh medium, counted in Neubauer chamber and the concentration adjusted to $4 \times 10^{6}$ cells $/ \mathrm{mL}$. The test was conducted in vitro. Substances were added at $320 \mu \mathrm{g} / \mathrm{mL}$ to $0.125 \mu \mathrm{g} / \mathrm{mL}$ solubilized in DMSO and incubated at $25^{\circ} \mathrm{C}$ for $24 \mathrm{~h}$. After this period, surviving parasites were counted in Neubauer chamber and compared with controls. Pentamidine isethionate (Eurofarma ${ }^{\circledR}$ ) was used as positive control drug and DMSO as negative control. The LD50/24 was determined by linear regression analysis of the inhibition percentage with $10 \%$ statistical error.

\section{ANTIBACTERIAL BIOASSAY}

Microorganisms' susceptibity to the polyketides test were determined by microbroth dilution assay as recommended by the Subcommittee on Antifungal Susceptibility Testing of the US National Committee for Clinical Laboratory Standards (NCCLS 1997).

\section{RESULTS AND DISCUSSION}

POLYKETIDES IDENTIFICATION

Compounds 1, 2 and 3 were identified by 1D and 2D NMR and MS spectral analyses in comparison with the literature and showed total similarity to the polyketides citreorosein (1), emodin (2) and janthinone (3) (Fujimoto et al. 2004, Cohen and Towers 1995, Marinho et al. 2005). Substances 4, 5 and 6 1D and 2D NMR and MS data are consistent with citrinin, citrinin $\mathrm{H} 1$ and dicitrinol, previously isolated by our team from P. janthinellum (Marinho and Rodrigues Filho 2011).

LEISHMANICIDAL TEST

The substance 2 inhibited $50 \%$ of parasites at 320 $\mu \mathrm{g} / \mathrm{mL}$ showing a promising result. However, substances 1 and 3 inhibited about $20 \%$ and $22 \%$ of parasites at $320 \mu \mathrm{g} / \mathrm{mL}$, respectively. It seems that the methyl hydroxylation in the substance 1 reduced the activity in more than $50 \%$. Results obtained in leishmanicidal tests with substances 1, 2 and 3 suggest that positions C-3 and C-6 must be reduced and oxidized, respectively, for there being activity, since when both positions are oxidized or reduced there is significant decrease in the activity presented. 


\section{ANTIMICROBIAL ACTIVITY}

The antibacterial activity of citreorosein (1) was examined in the presence of $E$. coli, P. aeruginosa and B. subtilis. Results were compared with those obtained for emodin (2) under the same conditions (Table I). In general, citreorosein is less active than emodin, except against E. coli, which stops growing in a medium containing $31.25 \mu \mathrm{g} / \mathrm{mL}$ of 1 .

TABLE I

Bacteria growth behavior in the presence of compounds 1 and 2 at different concentrations.

\begin{tabular}{|c|c|c|c|c|c|c|}
\hline \multirow{2}{*}{$\begin{array}{l}\text { Concentration } \\
\text { c }[\mu \mathrm{g} / \mathrm{mL}] \text { of } \\
\text { test compounds }\end{array}$} & \multicolumn{2}{|c|}{ E. coli } & \multicolumn{2}{|c|}{ P. aeruginosa } & \multicolumn{2}{|c|}{ B. subtilis } \\
\hline & 1 & 2 & 1 & 2 & 1 & 2 \\
\hline 500 & $=$ & $=$ & $=$ & $=$ & $=$ & $=$ \\
\hline 250 & $=$ & + & $=$ & $=$ & - & $=$ \\
\hline 125 & $=$ & + & $=$ & $=$ & + & - \\
\hline 62.50 & $=$ & + & $=$ & $=$ & + & - \\
\hline 31.25 & $=$ & + & + & - & + & - \\
\hline 15.63 & + & + & + & - & + & + \\
\hline 7.81 & + & + & + & - & + & + \\
\hline
\end{tabular}

$=$ bactericidal effect, - bacteriostatic effect, + no active.

\section{ACKNOWLEDGMENTS}

The authors thank the Fundação Amazônica Paraense de Amparo à Pesquisa (FAPESPA), Fundação de Amparo à Pesquisa do Estado de São Paulo (FAPESP), Conselho Nacional de Desenvolvimento Científico e Tecnológico (CNPq), Coordenação de Aperfeiçoamento de Pessoal de Ensino Superior (CAPES) and Ministério da Saúde (MS) for financial support.

\section{RESUMO}

Neste trabalho estamos relatando o isolamento por métodos clássicos de cromatografia de seis policetídeos de Penicillium herquei. Os compostos citreoseine (1), emodina (2), janthinona (3), citrinina (4), citrinina H1(5) e dicitrinol (6) foram identificados por métodos espectrais de RMN 1D e 2D e EM. Os compostos 1, 2 e 3 foram testados contra formas promastigotas de Leishmania brasiliensis e 1 e 2 também foram ensaiados contra a Escherichia coli, Pseudomonas aeruginosa e Bacillus subtilis e mostraram boa atividade.

Palavras-chave: policetídeos, ensaio biológico, $P$. herquei.

\section{REFERENCES}

COHEN PA AND TOWERS GHN. 1995. The antraquinones of Heterodermia obscurata. Phytochemistry 40: 911-915.

FUJimoto H, NAKAMURA E, OKUYAMA E AND ISHIBASHI M. 2004. Six immunosuppressive features from an Ascomycete, Zopfiella longicaudata, found in a screening study monitored by immunonodulatory activity. Chem Pharm Bull 52: 1005-1008.

HAMAYUN M ET AL. 2009. Cladosporium sphaerospermum as a new plant growth-promoting endophyte from the roots of Glycine max (L.) Merr. World J Microbiol Biotechnol 25: 627-632.

JARVIS BB AND MILLER JD. 1996. Natural Products, Complexity and Evolution. In: PHYTOCHEMICAL DIVERSITY AND REDUNDANCY IN ECOLOGICAL INTERACIONS. New York: Plenum Press, p. 265-293.

Li JY, SidHu RS, Ford E, Hess WM AND Strobel GA. 1998. The induction of taxol production in the endophytic fungus - Periconia sp from Torreya grandifolia. J Ind Microbiol Biotechnol 20: 259-264.

Marinho AMR AND Rodrigues Filho E. 2011. Dicitrinol, a Citrinin Dimer, Produced by Penicillium janthinellum. Helv Chim Acta 94: 835-841.

MARINHO AMR, RODRIGUES FILHO E, SANTOS LS AND MOITINHO MLR. 2005. Biologically active polyketides produced by Penicillium janthinellum isolated as an endophytic fungus from fruits of Melia azedarach. J Braz Chem Soc 16: 280-283.

NCCLS - NATIONAL COMMITTEE FOR CLINICAL LABORATORY STANDARDS. 1997. Methods for Dilution and Antimicrobial Susceptibility Tests for Bacteria that Grow Aerobically, NCCLS Approved Standard M7-A4, Wayne, PA.

Petrini O, Sieber TN, Toti L AND Viret O. 1992. Ecology, metabolite production, and substrate utilization in endophytic fungi. Natural Toxis 1: 185-196.

SANTOS RMG, RODRIGUES FILHO E, ROCHA WC AND TEIXEIRA MFS. 2003. Endophytic fungi from Melia azedarach. World J Microbiol Biotechnol 19: 767-770.

Shittu HO, CASTROverde DCM, NAZAR RN AND RoBB J. 2009. Plant-endophyte interplay protects tomato against a virulent Verticillium. Planta 229: 415-426

Stierle A, Strobel GA, Stierle D, Grothaus P AND BIGNAMI G. 1995. The search for a taxol-producing microorganism among the endophytic fungi of the pacific yew, Taxus brevifolia. J Nat Prod 58: 1315-1324. 